\title{
Inhibitory Activity of Plant Stilbene Oligomers against DNA Topoisomerase II
}

\author{
Masashi Yamada, ${ }^{a}$ Ken-ichiro Hayashi,,${ }^{b}$ Shogo IkedA,${ }^{b}$ Ken Tsutsui,${ }^{c}$ Kimiko Tsutsui, ${ }^{c}$ Tetsuro Ito, ${ }^{d}$ \\ Munekazu IINUMA, ${ }^{e}$ and Hiroshi NOZAKI ${ }^{*}, b$ \\ ${ }^{a}$ Meiji Dairies Corporation; 1-2-10 Shinsuna, Koto-ku, Tokyo 136-8908, Japan: ${ }^{b}$ Department of Biological Chemistry, \\ Faculty of Science, Okayama University of Science; 1-1 Ridai-cho, Okayama 700-0005, Japan: ${ }^{c}$ Graduate School of \\ Medicine, Dentistry and Pharmaceutical Science, Okayama University; 2-5-1 Shikatacho, Okayama 700-8558, Japan: \\ ${ }^{d}$ Gifu Prefectural Institute of Health and Environmental Sciences; 1-1 Naka-Fudogaoka, Kakamigahara, Gifu 504-0838, \\ Japan: and ${ }^{e}$ Department of Pharmacognosy, Gifu Pharmaceutical University; 5-6-1 Mitahora-higashi, Gifu 502-8585, \\ Japan. Received March 9, 2006; accepted April 5, 2006; published online April 18, 2006
}

The inhibitory activity of $\mathbf{4 0}$ stilbene oligomers isolated from six plant species against topoisomerase II was evaluated, of which nine compounds showed a potent inhibitory effect, stronger than daunorubicin, a topoisomerase II inhibitor, used as an anti-cancer drug. The specificity of active stilbene oligomers on topoisomerase II was assessed by their effect on DNA restriction enzyme. In particular, specific inhibitory activity was observed in $\alpha$-viniferin 13- $O$ - $\beta$-glucopryranoside (2) and hemsleyanol C (13).

Key words stilbene; topoisomerase; inhibitor

Type II DNA topoisomerases (topo II) catalyze topological changes in the DNA molecule through transient breakage and rejoining of double-stranded DNA. These reactions relax supercoiled DNA and catenate or decatenate covalently closed circular DNA. ${ }^{1)}$ Topo II are essential cellular enzymes required for cell proliferation and, therefore, are clinical targets for anti-cancer drugs. Although inhibitors against topo II have been developed and applied clinically, their severe sideeffects remain a serious problem. In the development of new inhibitors, natural products from plant sources can be valuable when used directly and may also serve as a suitable lead for the production of semi-synthetic active agents. In the continuous search for topo II inhibitors in plant extracts, we have found that stilbene oligomers, nepalensinols from Kobresia nepalensis, showed significant inhibitory activity against topo II. ${ }^{2,3}$ ) This finding prompt us to investigate topo II inhibitory activity of other stilbene oligomers. We herein report the inhibitory effect of 40 stilbene oligomers from six species of plant and their structure-activity correlation.

The inhibitory activity of stilbene oligomers $\mathbf{1}-\mathbf{4 0}$ against topo II was evaluated by their inhibitory effect against the decatenation activity of topo II on kinetoplast DNA. Initial screening for inhibition was performed at concentrations of 10,100 and $500 \mu \mathrm{g} / \mathrm{ml}$. The 35 stilbenes exhibiting inhibitory activity at less than $500 \mu \mathrm{g} / \mathrm{ml}$ were further analysed to determine their $\mathrm{IC}_{50}$ values against topo II and DNA restriction enzyme, HindIII. $\mathrm{IC}_{50}$ values, as determined from three individual experiments with three replicates for each concentration, are listed in Table 1 . Twelve compounds $(\mathbf{2}, \mathbf{6}$, $7, \mathbf{8}, \mathbf{9}, \mathbf{1 3}, \mathbf{1 4}, \mathbf{1 5}, \mathbf{2 1}, \mathbf{2 2}, \mathbf{2 8}, \mathbf{3 6})$ showed $\mathrm{IC}_{50}$ values ranging from 0.9 to $7.2 \mu \mathrm{M}$, which were stronger than the positive control, daunorubicin $(8.5 \mu \mathrm{M})$, a topo II inhibitor. In particular, compound 13 exhibited the most potent activity, which was eight times stronger than daunorubicin.

Compounds $\mathbf{1}$ and $\mathbf{2}$ are resveratrol trimers with a ninemembered ring, and $\mathbf{2}$ is the glucoside of $\mathbf{1}$ at the C-13b position. The inhibitory activity of $\mathbf{2}$ was stronger than that of 1-substitution of glucose resulting in increased activity in this type of stilbene. Resveratrol dimers $\mathbf{3 - 5}$, and trimer $\mathbf{6}$, have the same partial structure of a seven-membered ring. Compound $\mathbf{5}$, an epimer at C-7b of $\mathbf{4}$, was less active than $\mathbf{4}$. In addition, compound $\mathbf{3}$ is a stereoisomer at $\mathrm{C}-7 \mathrm{~b}$ and $\mathrm{C}-8 \mathrm{~b}$ of $\mathbf{4}$, and it displayed less activity than $\mathbf{5}$. On the other hand, compound $\mathbf{6}$, a resveratrol trimer, showed the most potent activity. On the basis of these finding, the stereochemistry (7b$\beta$ and $8 b-\alpha$ hydrogen) at $C-7 b$ and $C-8 b$, and the addition of a resveratrol unit, appears to be essential for inhibitory activity in this type of stilbene. Compounds $\mathbf{7 - 1 0}$ are resveratrol tetramers composed of two dimers with a seven-membered ring, and stereoisomers to each other. Different levels of inhibitory activity were seen in these compounds, i.e. compounds 7-9 showed significantly strong activity, while $\mathbf{1 0}$ was considerably less active. Their structural differences are in a symmetrical pattern, i.e. molecular structures in $\mathbf{7 - 9}$ are symmetrical and compound $\mathbf{1 0}$ is asymmetrical. Therefore, in this type of stilbene, an asymmetric pattern results in decreased inhibitory activity. This can be seen clearly where compounds 11 and $\mathbf{1 2}$ are inactive over $50 \mu \mathrm{M}$. Compounds 13-15 have the same partial structure with five- and sevenmembered rings. All three compounds showed significant activity higher than daunorubicin and compound $\mathbf{1 3}$ was the most potent of the stilbene oligomers examined in this assay. The slight difference of activity between these compounds seems to originate in the configuration pattern at $7 b, 8 b, 7 c$ and $8 \mathrm{c}$, and the addition of another resveratrol unit. Although compounds 16-21 also have the same partial structure, the linkage style with the third resveratrol unit is different from compounds 13, 14 and 15. Among compounds 16-21, only compound 21, a highly condensed resveratrol hexamer, showed comparatively high activity. However, the structureactivity correlation in this type of stilbene is unclear. Compound 22, a resveratrol trimer, was active at $5.3 \mu \mathrm{M}$ and more potent than $\mathbf{2 3}$ or $\mathbf{2 4}$. The addition of a resveratrol unit to $\mathbf{2 3}$ seems to produce an increase in activity. Compounds $\mathbf{2 5}-\mathbf{2 7}$ have same partial stereostructure, but compound 27 was inactive. The $\mathrm{C} 2$-asymmetrical nature and addition of a glucose moiety at $\mathrm{C}-12^{\prime}$ and $\mathrm{C}-12^{\prime \prime}$ in $\mathbf{2 6}$ caused a remarkable diminution in inhibitory activity. 

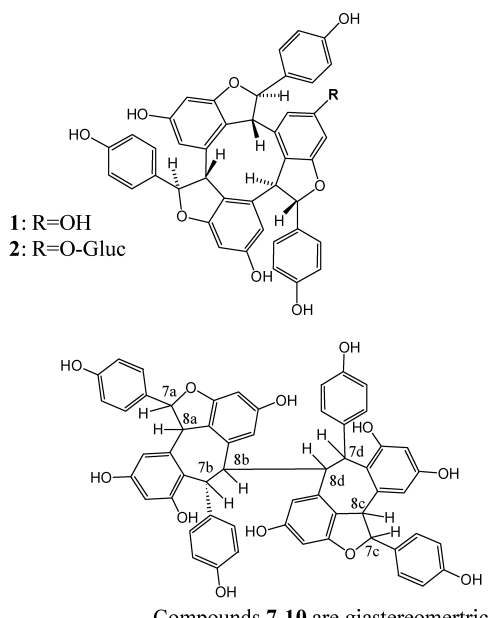

Compounds 7-10 are giastereomertric

7: symmetical; $(\mathrm{H}-7 \mathrm{a}, \mathrm{H}-8 \mathrm{a})=(\beta, \alpha) ;(\mathrm{H}-7 \mathrm{~b}, \mathrm{H}-8 \mathrm{~b})=(\beta, \alpha)$

8: symmetical; $(\mathrm{H}-7 \mathrm{a}, \mathrm{H}-8 \mathrm{a})=(\alpha, \beta) ;(\mathrm{H}-7 \mathrm{~b}, \mathrm{H}-8 \mathrm{~b})=(\beta, \alpha)$

9: symmetical; $(\mathrm{H}-7 \mathrm{a}, \mathrm{H}-8 \mathrm{a})=(\beta, \alpha)$; $(\mathrm{H}-7 \mathrm{~b}, \mathrm{H}-8 \mathrm{~b})=(\alpha, \alpha)$

10: asymmetical; $(\mathrm{H}-7 \mathrm{a}, \mathrm{H}-8 \mathrm{a})=(\alpha, \beta) ;(\mathrm{H}-7 \mathrm{~b}, \mathrm{H}-8 \mathrm{~b})=(\beta, \alpha)$ $(\mathrm{H}-7 \mathrm{c}, \mathrm{H}-8 \mathrm{c})=(\beta, \alpha) ;(\mathrm{H}-7 \mathrm{~d}, \mathrm{H}-8 \mathrm{~d})=(\beta, \alpha)$
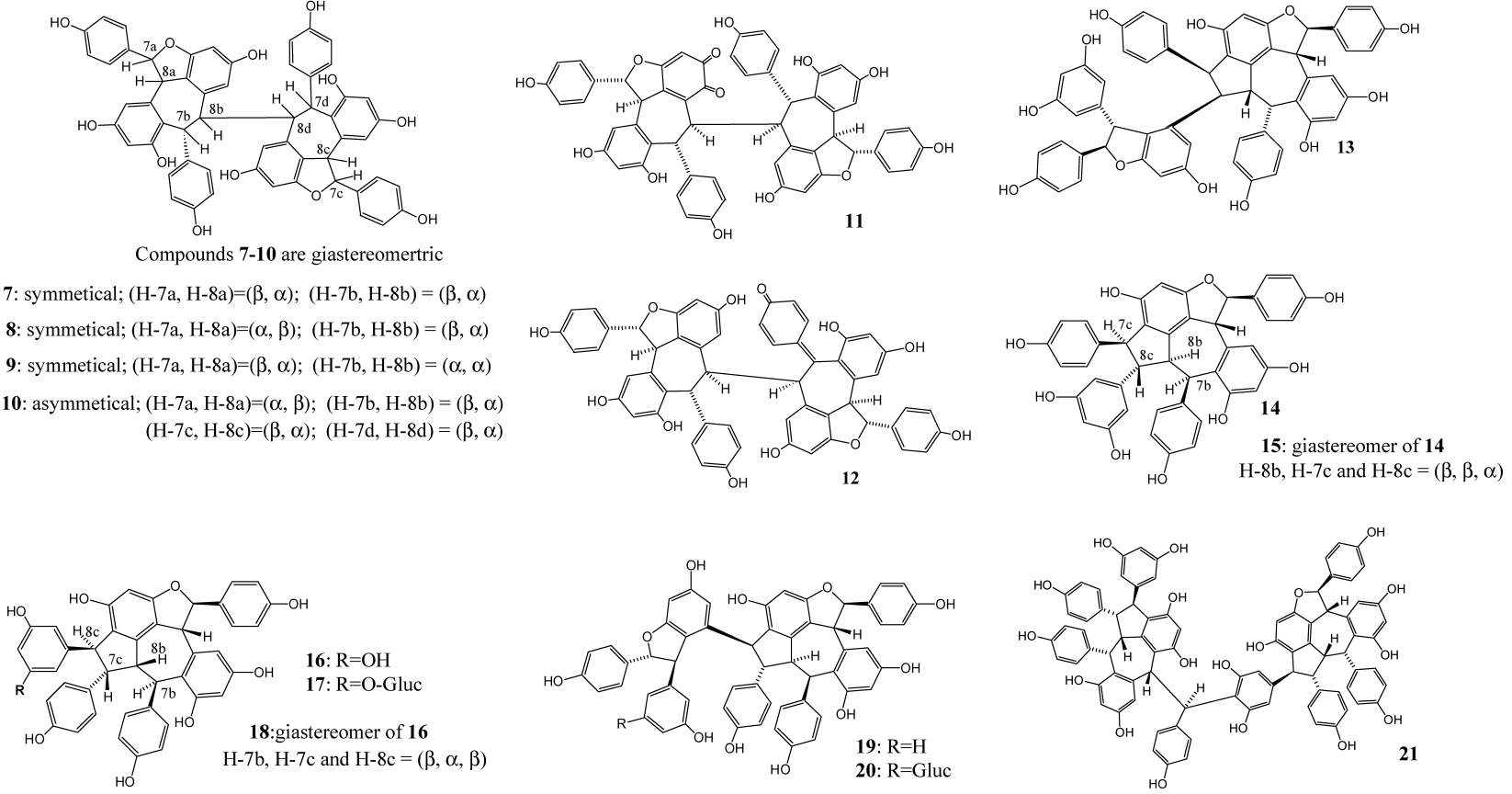
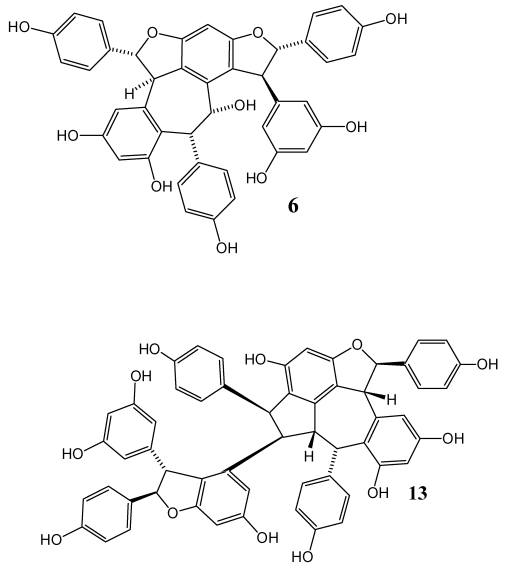

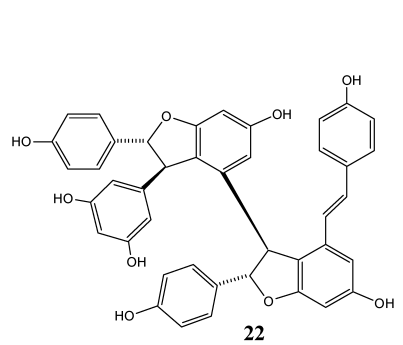

22

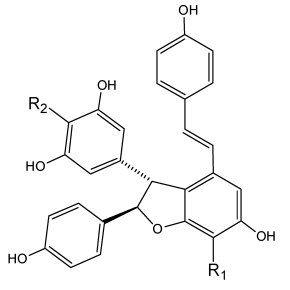

23: $\mathrm{R}_{1}, \mathrm{R}_{2}=\mathrm{H}$ 24: $\mathrm{R}_{1}, \mathrm{R}_{2}=\mathrm{O}$-Gluc

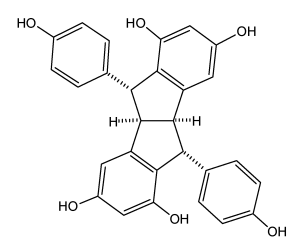

25
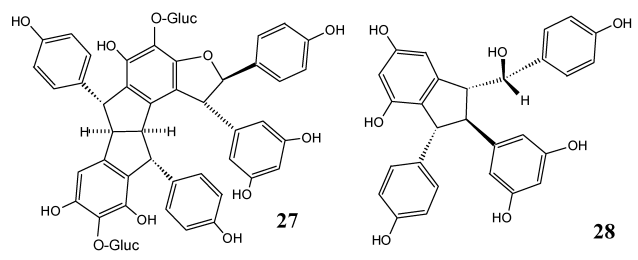

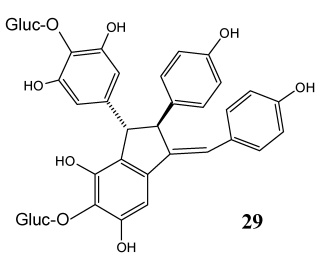

29

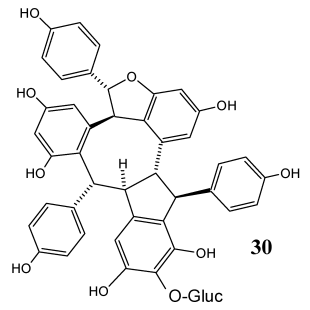

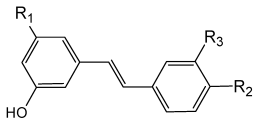

31: $\mathrm{R}_{1}=\mathrm{OH}, \mathrm{R}_{2}=\mathrm{OH}, \mathrm{R}_{3}=\mathrm{H}$ 32: $\mathrm{R}_{1}=\mathrm{O}-$ Gluc, $\mathrm{R}_{2}=\mathrm{OH}, \mathrm{R}_{3}=\mathrm{H}$ 33: $\mathrm{R}_{1}=\mathrm{OH}, \mathrm{R}_{2}=\mathrm{OH}, \mathrm{R}_{3}=\mathrm{OCH}_{3}$ 34: $\mathrm{R}_{1}=\mathrm{O}-\mathrm{Gluc}, \mathrm{R}_{2}=\mathrm{OH}, \mathrm{R}_{3}=\mathrm{OCH}_{3}$ 35: $\mathrm{R}_{1}=\mathrm{OH}, \mathrm{R}_{2}=\mathrm{O}-$ Gluc, $\mathrm{R}_{3}=\mathrm{OCH}_{3}$
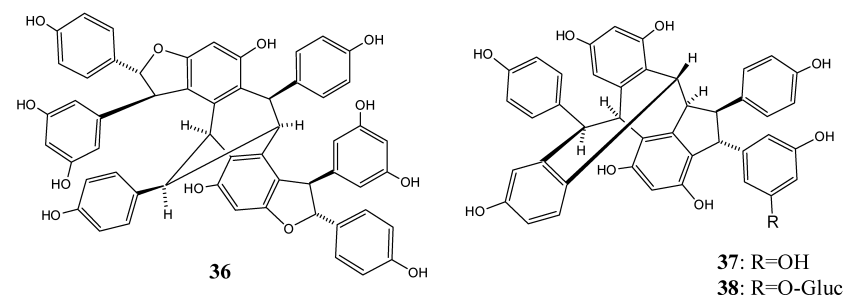

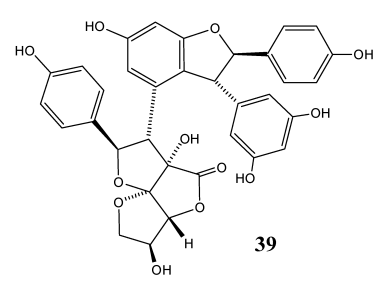


Table 1. Inhibitory Activity of Stilbene Oligomers against Topo II and HindIII

\begin{tabular}{|c|c|c|c|}
\hline Compounds & Topo $\mathrm{II}^{a)}$ & $H i n \mathrm{dIII}^{a)}$ & Specificity $\left.^{b}\right)$ \\
\hline Daunorubicin & 8.5 & 103.9 & 12.3 \\
\hline 1 & 27 & 68 & 3 \\
\hline 2 & 4 & 279 & 67 \\
\hline 3 & 145 & 268 & 2 \\
\hline 4 & 11 & 355 & 33 \\
\hline 5 & 47 & 523 & 11 \\
\hline 6 & 5 & 36 & 8 \\
\hline 7 & 6 & 33 & 6 \\
\hline 8 & 6 & n.d. & n.d. \\
\hline 9 & 4 & 78 & 22 \\
\hline 10 & 76 & 73 & 1 \\
\hline 11 & $>50$ & n.d. & n.d. \\
\hline 12 & $>50$ & n.d. & n.d. \\
\hline 13 & 1 & 69 & 80 \\
\hline 14 & 3 & n.d. & n.d. \\
\hline 15 & 6 & 143 & 23 \\
\hline 16 & 65 & 253 & 4 \\
\hline 17 & 77 & 594 & 8 \\
\hline 18 & 82 & 90 & 1 \\
\hline 19 & 70 & 97 & 1 \\
\hline 20 & 85 & 187 & 2 \\
\hline 21 & 5 & 12 & 2 \\
\hline 22 & 5 & 60 & 11 \\
\hline 23 & $>500$ & 415 & 1 \\
\hline 24 & 63 & 812 & 13 \\
\hline 25 & 11 & n.d. & n.d. \\
\hline 26 & 11 & 40 & 4 \\
\hline 27 & 483 & 483 & 1 \\
\hline 28 & 7 & n.d. & n.d. \\
\hline 29 & $>500$ & 617 & 1 \\
\hline 30 & 21 & 307 & 15 \\
\hline 31 & 262 & 500 & 2 \\
\hline 32 & 197 & 800 & 4 \\
\hline 33 & $>500$ & $>1000$ & n.d \\
\hline 34 & $>500$ & $>1000$ & n.d \\
\hline 35 & $>500$ & $>1000$ & n.d \\
\hline 36 & 7 & 104 & 14 \\
\hline 37 & 104 & 429 & 4 \\
\hline 38 & 88 & 594 & 7 \\
\hline 39 & 11 & 796 & 71 \\
\hline 40 & 26 & 148 & 6 \\
\hline
\end{tabular}

a) $\mathrm{IC}_{50}$ values $(\mu \mathrm{M}) . b$ ) Specificity values are indicated as the ratio of $\mathrm{IC}_{50}$ of HindIII to topo II. n.d.: not determined.

To evaluate the specificity of active stilbenes on topo II inhibition, the effect of these compounds on the activity of a HindIII restriction enzyme was examined. HindIII enzyme recognizes DNA as a substrate and catalyzes the cleavage of DNA at a specific sequence. Compounds 2, 9, 13 and 15 displayed higher activity and specificity for topo II than daunorubicin. In particular, the specificity value (ratio of $\mathrm{IC}_{50}$ of HindIII to topo II) of $\mathbf{2}$ and $\mathbf{1 3}$ was over 60. These compounds, therefore, could be suitable candidates as specific inhibitors of topo II.

Some topoisomerase inhibitors such as doxorubicin, amsacrine and ellipticine are DNA intercalators. In order to determine the DNA binding activity of several stilbene oligomers isolated in this study, ethidium bromide competition assay was carried out using salmon sperm DNA. Two compounds $(\mathbf{5}, \mathbf{2 1})$ competed with ethidium bromide for DNA, indicating that the stilbenes have some ability to intercalate into DNA strand (data not shown). Further analysis would clarify the inhibitory mechanism of the stilbenes on topo II.

\section{MATERIALS AND METHODS}

Compounds Stilbene oligomers were isolated from Shorea hemsleyana ${ }^{4-7)}$ (compounds 2, 3, 6, 9, 13, 15, 24, 27, 29, 30, 39), Vatica rassak ${ }^{8-10)}(\mathbf{1 6}-\mathbf{2 1}, \mathbf{2 3}, \mathbf{3 1}, \mathbf{3 2}, \mathbf{3 6}-\mathbf{3 8})$, Vatica indica $^{11)}(\mathbf{4}, \mathbf{1 0}, \mathbf{2 6})$, Hopea utilis ${ }^{12)}(\mathbf{5}, 40)$, Gnetum parvifolium $^{13)}(\mathbf{3 3}, \mathbf{3 4}, \mathbf{3 5})$, Kobresia nepalensis ${ }^{2,3,23)}(\mathbf{8}, \mathbf{1 1}$, 12, 14, 22, 25, 28), and two stilbenoids $(1,7)$ from Shorea hemsleyana ${ }^{4)}$ and Kobresia nepalensis, respectively.

Plant Materials Shorea hemslyeyana and Vaterica rassak were collected in Indonesia in October 1997, Vateria india and Hopea utilis in India in August 1999, Gnetum parvifalium in the Botanical Garden of the University of Tokyo in April 1999, and Kobresia nepalensis in Himalaya, Nepal in August 1995.

Topoisomerase II Assay Purified human topoisomerase II (topo II) was purchased from TopoGen, Inc. (U.S.A.) and kinetoplast DNA was purified from Crithidia fasciculata with cesium chloride using step-gradient centrifugation, as described in a previous report. ${ }^{15}$ ) Topo II activity was assessed by a decatenation reaction of kinetoplast DNA. ${ }^{16)}$ The assay was performed in a reaction mixture $(20 \mu \mathrm{l})$ containing $50 \mathrm{~mm}$ Tris- $\mathrm{HCl}$ (pH 7.9), $120 \mathrm{~mm} \mathrm{KCl}, 10 \mathrm{~mm} \mathrm{MgCl}_{2}, 0.5$ $\mathrm{mm}$ dithiothreitol, $0.5 \mathrm{~mm}$ EDTA ( $\mathrm{pH} 8.0$ ), $0.5 \mathrm{~mm}$ ATP, 30 $\mu \mathrm{g} / \mathrm{ml}$ bovine serum albumin and $0.25 \mu \mathrm{g} / \mathrm{ml}$ of kinetoplast DNA, as described previously. ${ }^{17)}$ A DMSO solution of the stilbenoids was added to the reaction mixture to give the desired concentrations. The reaction was initiated by adding $1 \mu \mathrm{l}$ of topo II $(0.75 \mathrm{U})$. After incubation at $30^{\circ} \mathrm{C}$ for $30 \mathrm{~min}$, the reaction was terminated by addition of $4 \mu \mathrm{l}$ of the solution $(0.66 \% \mathrm{SDS}$ and $0.33 \mathrm{mg} / \mathrm{ml}$ proteinase $\mathrm{K})$ prior to analysis of DNA products by $0.8 \%$ agarose gel electrophoresis. Gels were stained with ethidium bromide and photographed under UV light. Monomer minicircles released from the kinetoplast DNA were quantified by NIH image software (NIH, Bethesda, MD, U.S.A.).

HindIII Assay HindIII activity was assessed by conversion of supercoiled plasmid DNA to the linear form. The assay was performed in a reaction mixture $(20 \mu \mathrm{l})$ containing $10 \mathrm{~mm}$ Tris- $\mathrm{HCl}$ (pH 7.9), $50 \mathrm{~mm} \mathrm{NaCl}, 10 \mathrm{~mm} \mathrm{MgCl}_{2}$, and 200 ng of pBluescript SK(-) DNA with or without test compounds. The reaction was started by adding $1 \mu \mathrm{l}$ of HindIII (1.25 U; New England Biolab., U.S.A.). After incubation at $37^{\circ} \mathrm{C}$ for $60 \mathrm{~min}$, the plasmids were separated by agarose gel electrophoresis in the presence of ethidium bromide. The linear form DNAs generated by HindIII reaction were quantified by densitometry.

\section{REFERENCES}

1) D’Arpa P., Liu L. F., Biochim. Biophys. Acta, 989, 163-177 (1989).

2) Yamada M., Hayashi K., Hayashi H., Ikeda S., Hoshino T., Tsutsui Ke., Tsutsui Ki., Inuma M., Nozaki H., Phytochemistry, 67, 307-313 (2006).

3) Yamada M., Hayashi K., Hayashi H., Tsuji R., Kakumoto K., Ikeda S., Hoshino T., Tsutsui Ke., Tsutsui Ki., Ito T., Iinuma M., Nozaki H., Chem. Pharm. Bull., 54, 354-358 (2006).

4) Ito T., Tanaka T., Ido Y., Nakaya K., Iinuma M., Riswan S., Chem. Pharm. Bull., 48, 1001-1005 (2000).

5) Ito T., Tanaka T., Iinuma M., Nakaya K., Takahashi Y., Nakamura H., Nakagawa H., Riswan S., Helv. Chim. Acta, 86, 3394-3401 (2003). 
6) Tanaka T., Ito T., Nakaya K., Iinuma M., Takahashi Y., Naganawa H., Riswan S., Heterocycles 55, 729-740 (2001).

7) Ito T., Tanaka T., Ido Y., Nakaya K., Inuma M., Riswan S., Chem. Pharm. Bull., 48, 1959-1963 (2000).

8) Tanaka T., Ito T., Nakaya K., Inuma M., Riswan S., Phytochemistry, 54, 63-69 (2000).

9) Ito T., Tanaka T., Nakaya K., Iinuma M., Takahashi Y., Naganawa H., Ohyama M., Nakanishi Y., Bastow K. F., Lee K. H., Tetrahedron, 57, 7309-7321 (2001).

10) Ito T., Tanaka T., Ido Y., Nakaya K., Iinuma M., Takahashi Y., Naganawa H., Riswan S., Heterocycles, 55, 557-567 (2001).

11) Ito T., Tanaka T., Iinuma M., Nakaya K., Takahashi Y., Sawa R., Naganawa H., Chelladurai V., Tetrahedron, 59, 1255-1264 (2003).
12) Tanaka T., Ito T., Ido Y., Nakaya K., Iinuma M., Chelladurai V., Chem. Pharm. Bull., 49, 785-787 (2001).

13) Tanaka T., Iliya I., Ito T., Furusawa M., Nakaya K., Iinuma M., Shirataki Y., Matsuura N., Ubukata M., Murai J., Shimozono F., Hirai K., Chem. Pharm. Bull., 49, 858-862 (2001).

14) Ohyama M., Tanaka T., Inuma M., Burandt C. L., Chem. Pharm. Bull., 46, 663-668 (1998).

15) Englund P. T., J. Biol. Chem., 254, 4895-4900 (1979).

16) Miller K. G., Liu L. F., Englund P. T., J. Biol. Chem., 256, 9334-9339 (1981).

17) Tsutsui K. E., Tsutsui K. I., Sakurai H., Shohmori T., Oda T., Biochem. Biophys. Res. Commun., 138, 1116-1122 (1986). 